\title{
Sistem Informasi Penjualan pada Karo Rumah Mode di Simalingkar berbasis Web
}

\author{
${ }^{1}$ Mariani Sinaga \\ UNIKA ST. Thomas SU, JI. Setiabudi No 479 F Tanjungsari, Medan, Sumatera Utara, Indonesia \\ Email : marianisinaga96@gmail.com \\ ${ }^{2}$ Emerson P. Malau \\ UNIKA ST. Thomas SU, Jl. Setiabudi No 479 F Tanjungsari, Medan, Sumatera Utara, Indonesia \\ Email : malauemerson@gmail.com
}

\begin{abstract}
This study discusses the web-based sales information system at the Rumah Mode Karo store which has a collection of different men's and women's clothing products for sale. In addition to selling clothing collections, karo fashion houses also sell Tupperware. Karo Rumah Mode currently still sells directly and does not have a sales information system so that it causes problems such as recording the Karo Rumah Mode sales transaction data still manually, the store is difficult to control all products that have been sold and those that have not been sold, nor is the store know how much stock is still available for each type of product, who receives money on the sale of a product is also not well-documented and clear. Then from the problems that arise the proposed solution to overcome this problem is to build a sales information system that uses the PHP programming language and MYSQL as the database. The goal is a web-based information system that is built can make sales both online and directly in the store and facilitate users in sales transactions, report inventory and receipt of money against sales transactions are well-documented and clear. The method used in this study is literature study and interviews / case studies at fashion house karo stores.
\end{abstract}

Kata kunci : Sistem Informasi, Penjualan, Web, Php, Mysql.

\section{PENDAHULUAN}

Karo Rumah Mode merupakan Toko yang mempunyai koleksi produk-produk pakaian yang berbeda untuk di jual seperti kemeja pria dan wanita, dress, rok, celana panjang pria dan wanita, jaket pria dan wanita, celana pendek pria dan wanita. Selain menjual koleksi pakaian, karo rumah mode juga menjual Tupperware agar menambah koleksi produk di Karo Rumah Mode tersebut, yang didirikan untuk melengkapi kebutuhan pelanggan dari berbagai daerah. Karo Rumah Mode berbasis dan beralamat di kota Medan, Sumatera Utara.

Sistem penjualan yang digunakan di Karo Rumah Mode saat ini masih menjual secara langsung dan belum memiliki sistem informasi penjualan sehingga menimbulkan masalah seperti dalam pencatatan data maupun transaksi penjualan Karo Rumah Mode masih secara manual, oleh karena hal tersebut toko tersebut sulit dalam mengontrol semua produk yang sudah laku terjual maupun yang belum terjual. Toko tersebut juga tidak tahu berapa stok barang yang masih ada untuk setiap jenis produk, siapa yang menerima uang terhadap penjualan sebuah produk juga tidak terdokumentasi dengan baik dan jelas. Solusi yang diajukan untuk mengatasi masalah Karo Rumah Mode untuk mengembangkan bisnis penjualannya yaitu E-Commerce dimana memperkenalkan/menjual secara online semua produk yang ada dan penjualan juga dapat dilakukan langsung di toko.

E-Commerce merupakan suatu kontak transaksi perdagangan antara penjual dan pembeli dengan menggunakan media internet. Keuntungan yang diperoleh dengan menggunakan transaksi melalui sistem adalah untuk meningkatkan pendapatan dengan menggunakan penjualan online yang biayanya lebih murah dan juga sekaligus biaya-biaya operasional seperti kertas, pencetakan katalog [8].

\section{LANDASAN TEORI}

\subsection{Sistem Informasi Penjualan}

Menurut Marconi (2011) sistem informasi penjualan adalah sub sistem informasi bisnis yang mencakup kumpulan prosedur yang melaksanakan, mencatat, mengkalkulasi, membuat dokumen dan informasi penjualan 
untuk keperluan manajemen dan bagian lain yang berkepentingan, mulai dari diterimanya order penjualan sampai mencatat timbulnya tagihan atau piutang dagang [3]. Berdasarkan pengertian di atas, dapat disimpulkan bahwa komponen-komponen dari sistem informasi penjualan secara umum terdiri dari:

a. Pencatatan transaksi penjualan

b. Pengecekan stok barang

c. Kalkulasi jumlah dan harga

d. Pembuatan dan pencetakan nota penjualan

e. Pembuatan dokumen atau informasi penjualan untuk keperluan manajemen

Dalam sistem yang dibangun, komponen pencatatan transaksi penjualan, pengecekan stok barang, kalkulasi jumlah dan harga beserta pembuatan dan pencetakan laporan penjualan masuk dalam sub sistem point of sales. Sedangkan dokumen atau informasi penjualan untuk keperluan manajemen akan menjadi output dari sistem informasi yang dibangun.

\subsection{E - Commerce}

E-commerce merupakan kegiatan bisnis yang menyangkut konsumen (consumers), manufaktur (manufactures), serviceproviders dan pedagang perantara (intermediaries) dengan menggunakan jaringan komputer (computernetworks) yaitu internet. Penggunaan sarana internet merupakan suatu kemajuan teknologi yang dapat dikatakan menunjang secara keseluruhan spektrum kegiatan komersial (Mawardi, 2008) dalam [10]. Ada beberapa definisi E-Commerce dari beberpa sumber diantaranya adalah sebagai berikut :

1. Berhubungan dengan pembelian dan penjualan barang atau jasa melalui Internet, khususnya Word Wide Web.

2. Suatu tindakan melakukan transaksi bisnis secara elektronik dengan menggunakan Internet sebagai media komunikasi yang paling utama.

3. Menjual barang dagangan atau jasa melalui Internet.

E-Commerce akan merubah semua kegiatan marketing dan juga memangkas biaya-biaya operasional untuk kegiatan tranding (perdagangan). Adapun proses yang terjadi dalam E-Commerce adalah sebagai berikut :
a. Presentasi Elektronis (Pembuatan Website) untuk produk dan layanan.
b. Pemesanan secara langsung dan tersedianya tagihan
c. Otomasi account pelanggan secara aman (nomor rekening ataupun kartu kredit)

d. Pembayaran dilakukan secara langsung (online)

Resiko dan kerugian E-Commerce :

1. Kehilangan segi financial secara langsung karena kecurangan .

2. Pecurian informasi rahasia berharga

3. Kehilangan kesempatan bisnis karena gangguan pelayanan

4. Penggunaan akses ke sumber oleh pihak yang tidak berhak

5. Kehilangan kepercayaan dari para konsumen

\subsection{Metode Pembayaran Dalam Transaksi Ecommerce}

Beberapa motivasi bagi pebisnis untuk memfasilitasi pembayaran online bagi pelanggannya melalui suatu penyedia layanan pembayaran online adalah sebagai berikut (Lowry et al, 2006) [2].

1. Meningkatkan efisiensi cash flow.

2. Transaksi yang terjamin.

3. Biaya operasional yang lebih hemat.

4. Meningkatkan proteksi informasi sensitif. Sementara itu, bentuk pembayaran pada toko online menggunakan media internet, tata cara pembayaran (transaksi) dapat dibagi menjadi lima mekanisme utama yaitu :

a. Transaksi model ATM. Transaksi ini hanya melibatkan toko online dan pemegang account yang akan melakukan pembayaran dari account masing-masing.

b. Pembayaran dua pihak tanpa perantara, transaksi dilakukan langsung pada kasir toko online (Cash Money).

c. Pembayaran dengan perantaran pihak ketiga, umumnya proses pembayaran yang menyangkut debit, kredit maupun cek masuk dalam kategori ini. Ada beberapa metode pembayaran yang dapat digunakan, yaitu : sistem pembayaran kartu kredit online dan sistem pembayaran check online.

d. Micropayment, transaksi ini penting dikembangkan karena sangat diperlukan pembayaran receh yang kecil tanpa overhead transaksi yang tinggi pada toko online.

e. Anonymous digital cash, yaitu uang elektronik yang di enkripsi.Uang elektronik Menjamin privacy dari user cash tetap terjamin sama seperti uang kertas maupun coin yang kita kenal.

\section{HASIL DAN PEMBAHASAN}

Analisis sistem yang berjalan menjelaskan sistem yang saat ini ada pada Karo Rumah Mode yang mencakup prosedur penjualan barang, prosedur pembuatan laporan

Sistem Informasi Penjualan pada Karo Rumah Mode di Simalingkar berbasis Web. $\quad 50$

Oleh : ${ }^{1}$ Mariani Sinaga, ${ }^{2}$ Emerson P. Malau 
penjualan [11]. Prosedur penjualan yang ada di karo rumah mode terdiri dari :

1. Konsumen datang ke toko untuk melihat dan memilih barang yg diinginkan kemudian langsung melakukan transaksi kepada penjual ditoko.

2. Bagian penjualan akan mengecek apakah stok masih ada atau tidak.

3. Konsumen melakukan pembayaran langsung di toko.

4. Penjualan juga dapat dilakukan dengan cara toko tersebut menerima Reseller, dimana reseller membawa barang dari toko untuk di jual di luar dengan harga yg di buat oleh reseller sendiri tanpa memberi jaminan.

5. Jika barang laku di jual oleh reseller maka reseller mengembalikan modal kepada Karo Rumah Mode.

6. Jika barang yang di bawa oleh Reseller tidak laku maka barang tersebut bisa di kembalikan ke toko.

Prosedur pembuatan laporan bulanan yang ada di Karo Rumah Mode terdiri dari :

1. Bagian penjualan mengambil rincian rencana produksi di arsip rincian rencana produksi dan rincian pasokan di arsip rincian pasokan.

2. Kemudian dari kedua jenis data tersebut dibuat laporan penjualan bulanan untuk mendapatkan informasi penjualan bulanan. Setelah dibuat laporan, masing-masing data kembali diarsipkan.

3. Setelah dicek, laporan penjualan diberikan kepada pemilik toko.

4. Pemilik toko mengecek laporan tersebut dan mengarsipkannya ke arsip laporan penjualan.

\subsection{Perancangan Sistem}

Setelah menganalisis sistem yang sedang berjalan maka dapat dibuat rancangan sistem yang akan di bangun[5]. Model atau gambaran sistem yang dirancang disajikan dalam diagaram UML (Unified Modeling Language). Dengan diagram UML secara logika dapat diketahui kebutuhan sistem serta kesatuan yang terlibat membangun sebuah system [6].
Use Case Sistem informasi penjualan pada Karo Rumah Mode di Simalingkar berbasis web dapat dilihat seperti pada Gambar 1. Dari gambar use case tersebut dapat dijelaskan bahwa terdapat 5 aktor dan beberapa proses. Setiap proses yang ditangani aktor akan dijelaskan sebagai berikut:

1) Admin

Sebelum menangani setiap proses, admin harus melakukan login terlebih dahulu. Adapun proses yang akan ditangani seorang admin adalah mendaftarkan operator, kasir, pemilik, menambah maupun menghapus produk, mengkonfirmasi order dari pembeli serta mengkonfirmasi pembayaran.

2) Operator

Sebelum menangani setiap proses, Operator harus melakukan login terlebih dahulu. Adapun proses yang akan ditangani seorang operator adalah menambah maupun menghapus produk, mengkonfirmasi order dari pembeli serta konfirmasi pembayaran.

\section{3) Pemilik}

Sebelum menangani setiap proses, Pemilik harus melakukan login terlebih dahulu. Adapun proses yang akan ditangani seorang owner adalah melihat laporan penjualan.

4) Kasir

Sebelum menangani setiap proses, Kasir harus melakukan login terlebih dahulu. Adapun proses yang akan ditangani seorang kasir adalah proses pencarian produk dan proses transaksi penjualan secara langsung.

5) Customer

Sebelum menangani setiap proses, Customer harus melakukan login terlebih dahulu. Adapun proses yang akan dilakukan seorang Customer adalah proses pencarian produk, proses order produk, proses mengubah data diri dan password. 


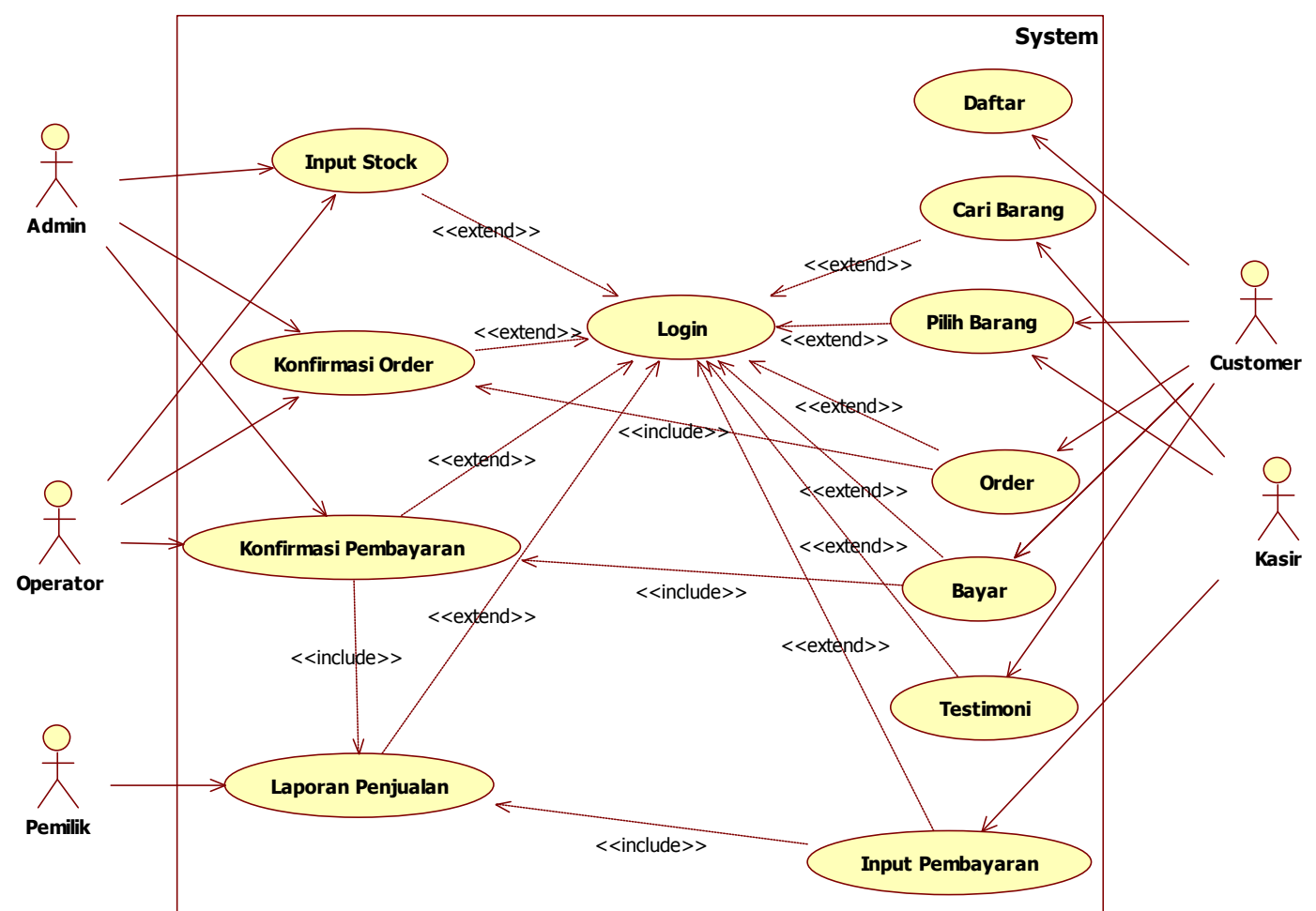

Gambar 1. Use case Sistem Informasi Penjualan Pada Karo Rumah Mode di Simalingkar

\subsection{Relasi Tabel Database}

Dari gambaran rancangan UML diatas dapat diketahui kebutuhan database yang diperlukan oleh sistem. Adapun relasi table pada pembangunan sistem informasi penjualan pada karo rumah mode di Simalingkar adalah dapat dilihat pada Gambar 2.

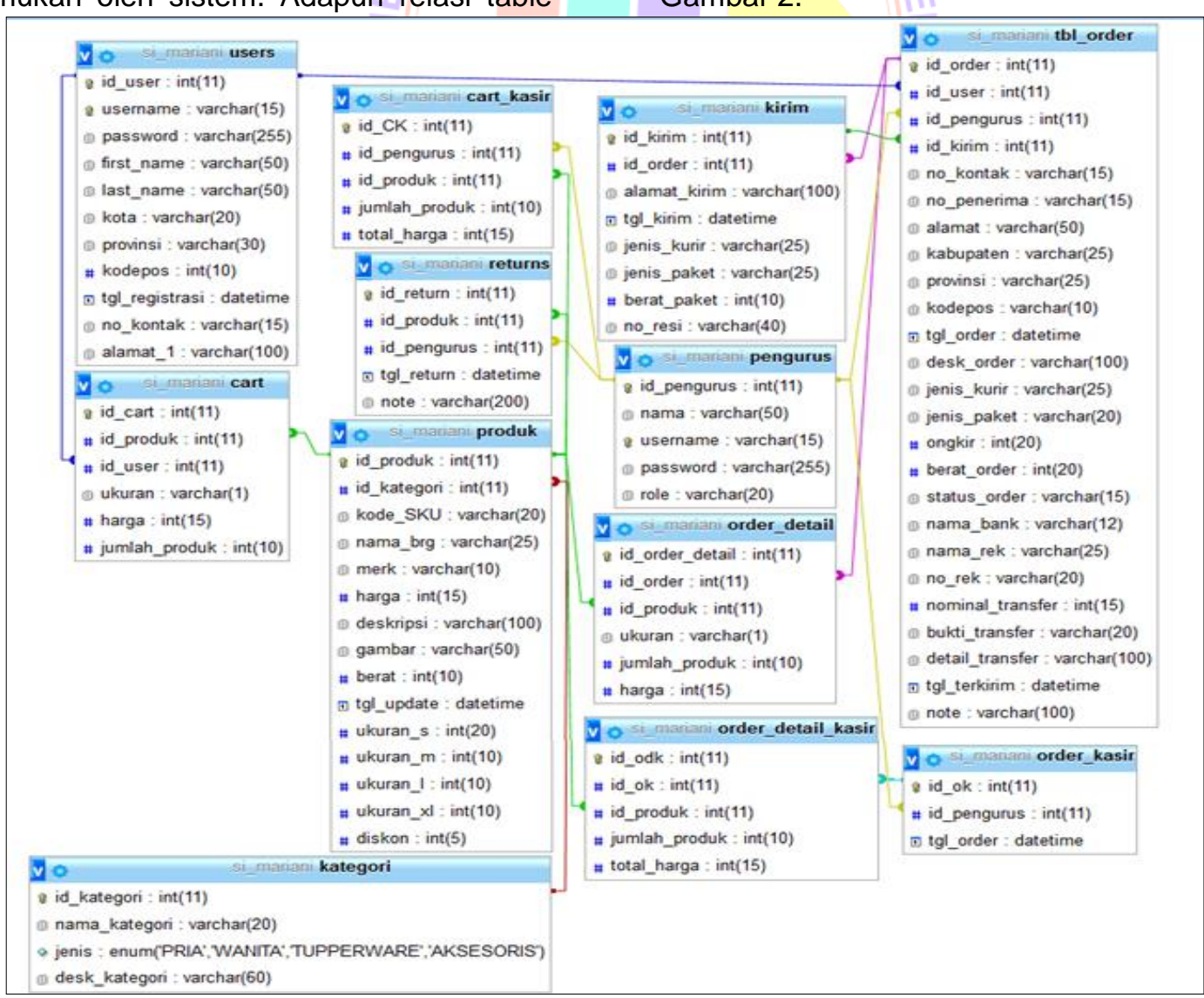

Gambar 2. Relasi Antar Tabel 


\subsection{Implementasi Sistem}

Implementasi sistem informasi penjualan pada karo rumah mode terdiri dari halaman login untuk admin dan pemilik seperti pada Gambar 3 , halaman utama admin seperti pada Gambar 4 , halaman daftar pesanan oleh admin seperti pada Gambar 5, halaman konfirmasi pembayaran oleh admin seperti pada Gambar 6 , halaman daftar produk oleh admin seperti pada Gambar 7.

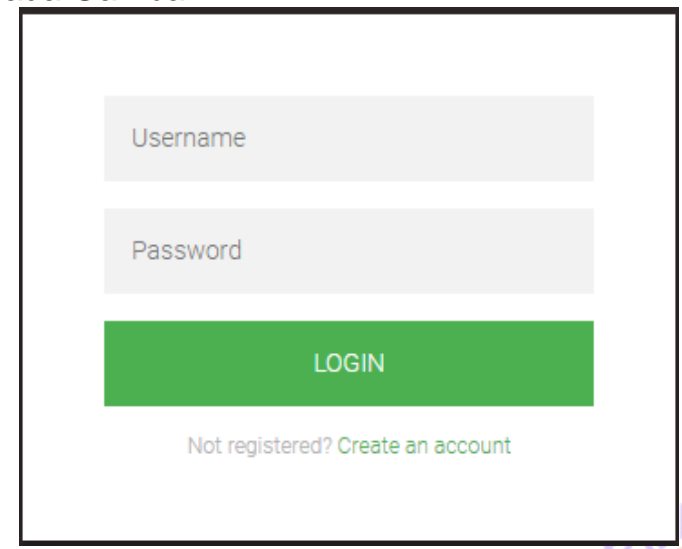

Gambar 3. Halaman Login admin

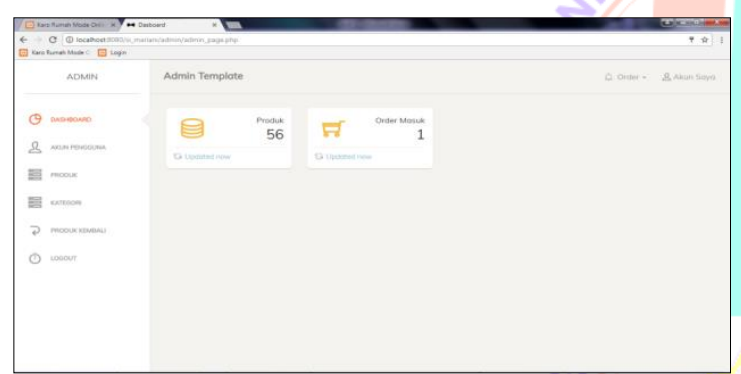

Gambar 4. Halaman Utama Admin

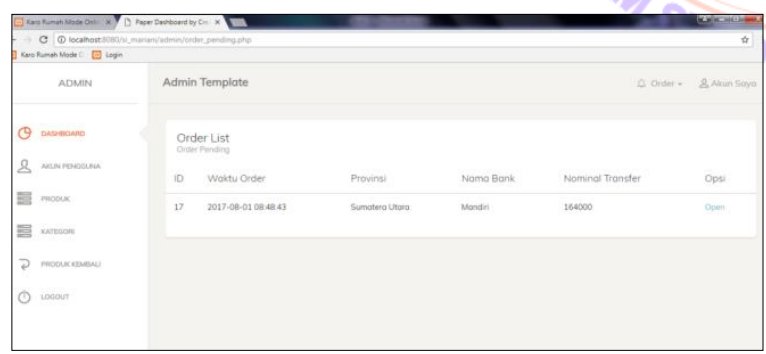

Gambar 5. Halaman Daftar Pesanan

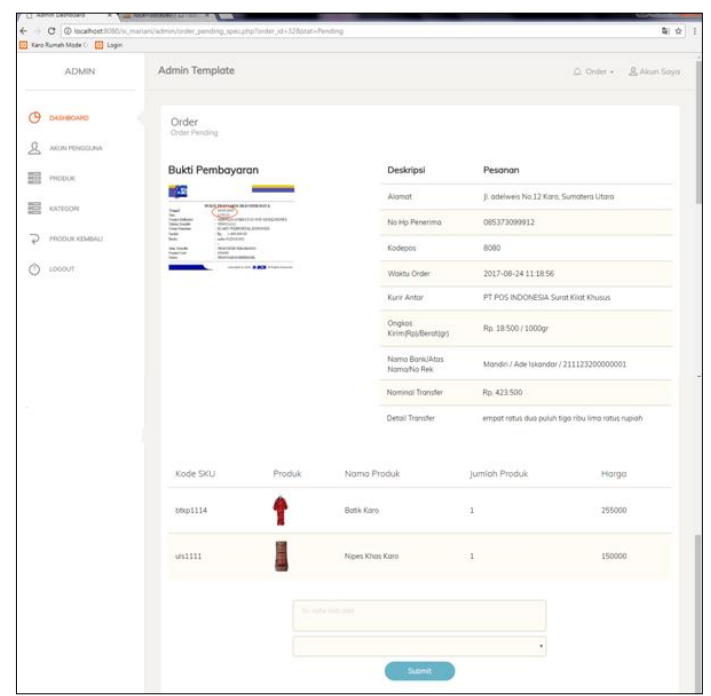

Gambar 7. Halaman Daftar Produk

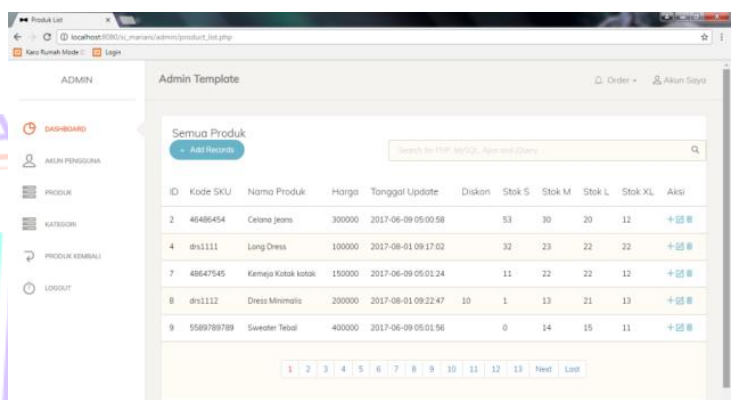

Gambar 6. Halaman Konfirmasi Pembayaran

Halaman untuk menambah produk sperti pada Gambar 8, halaman untuk melakukan penjualan langsung ditoko yang dilakukan oleh kasir dapat dilihat pada Gambar 9, halaman jual produk dimana berisi informasi produk yang di beli pelanggan saat penjualan langsung ditoko oleh kasir ditunjukkan pada Gambar 10.

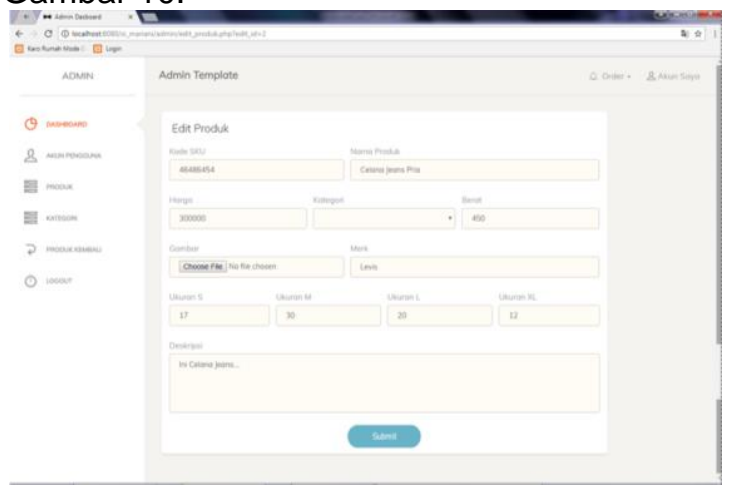

Gambar 8. Halaman Input Produk 


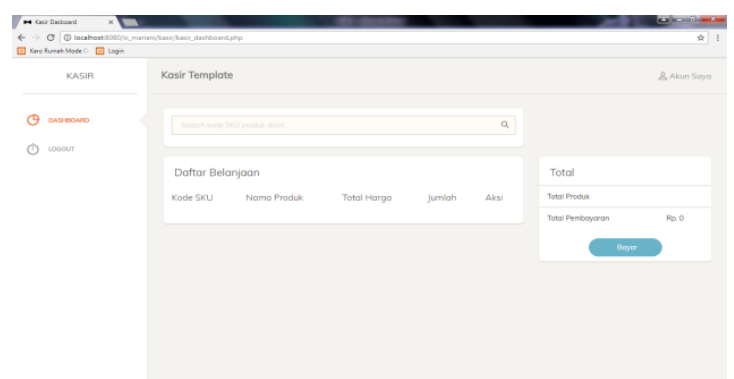

Gambar 9. Halaman Utama Kasir

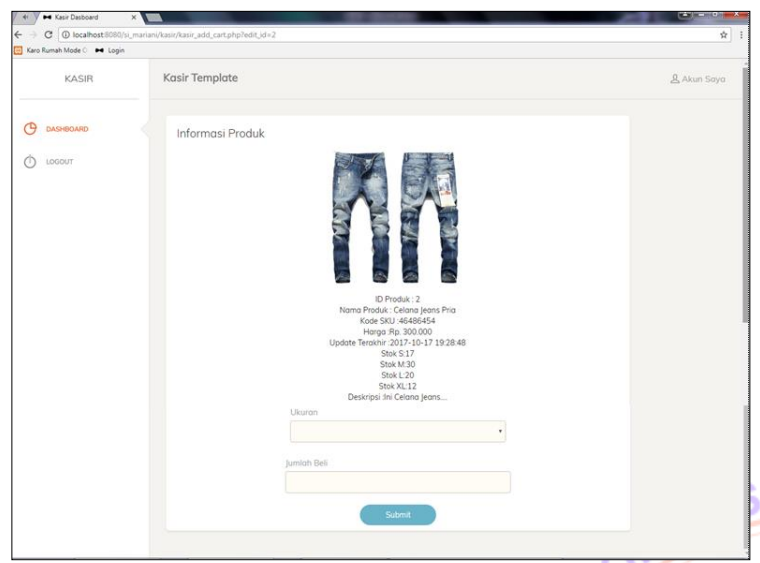

Gambar 10. Halaman Jual Produk

Halaman utaman pembeli adalah halaman yang bisa di lihat oleh siapa saja yang mengunjungi website karo rumah mode ditunjukkan seperti pada Gambar 11.

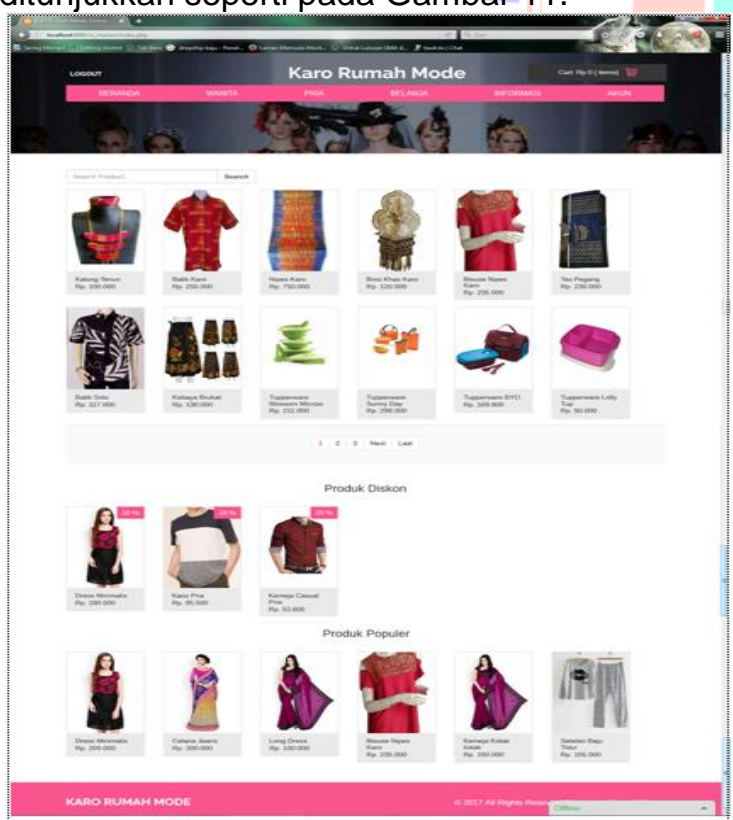

Gambar 11. Halaman Utama Pembeli

Halaman untuk menampilkan informasi detail produk yang dipilih oleh pembeli dapat dilihat pada Gambar 12, Halaman untuk menampilkan informasi daftar produk-produk yang dipilih pembeli untuk kemudian di proses kepemesanan dapat dilihat pada Gambar 13.

Sistem Informasi Penjualan pada Karo Rumah Mode di Simalingkar berbasis Web.

Oleh : ${ }^{1}$ Mariani Sinaga, ${ }^{2}$ Emerson P. Malau

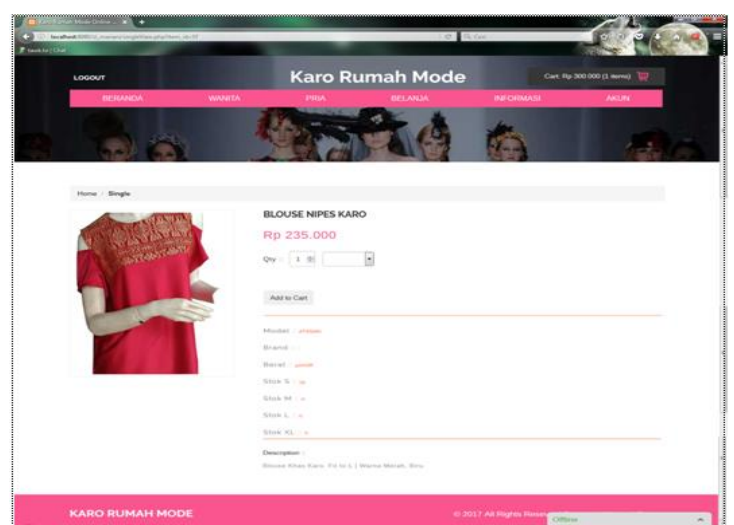

Gambar 12. Halaman Informasi Produk

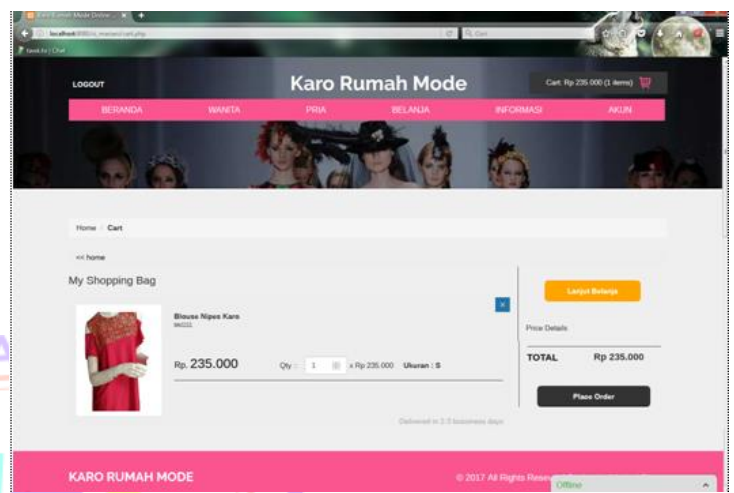

Gambar 13. Halaman Keranjang Belanja

Halaman untuk memesan produk yang sudah terdaftar didalam keranjang belanja(cart) dan menampilkan formulir untuk diisi informasi pesanan suatu produk yang dipilih pembeli dapat dilihat pada Gambar 14, Halaman untuk melanjutkan proses order yaitu melakukan transaksi pembayaran, form-form yang terdapat pada halaman tersebut diisi sesuai data yang sebenarnya oleh pembeli ditunjukkan pada Gambar 15.

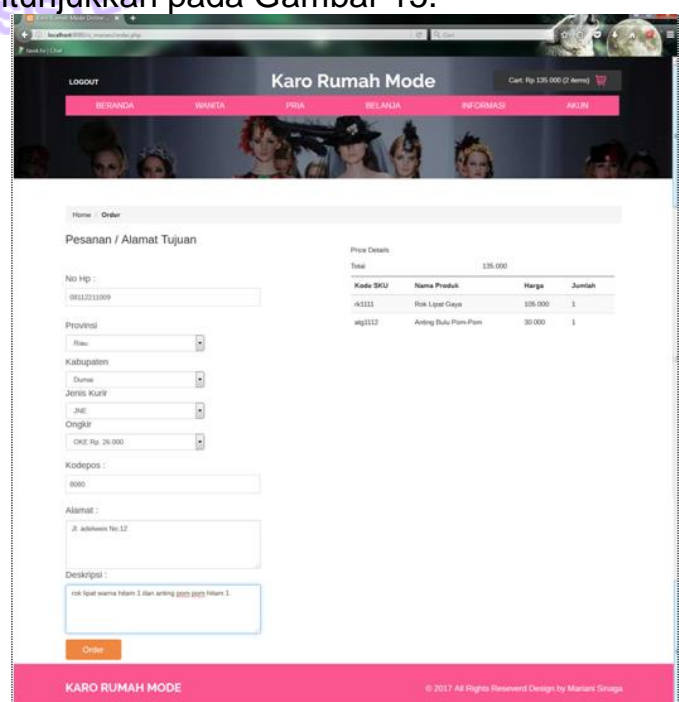

Gambar 14. Halaman Pemesanan 


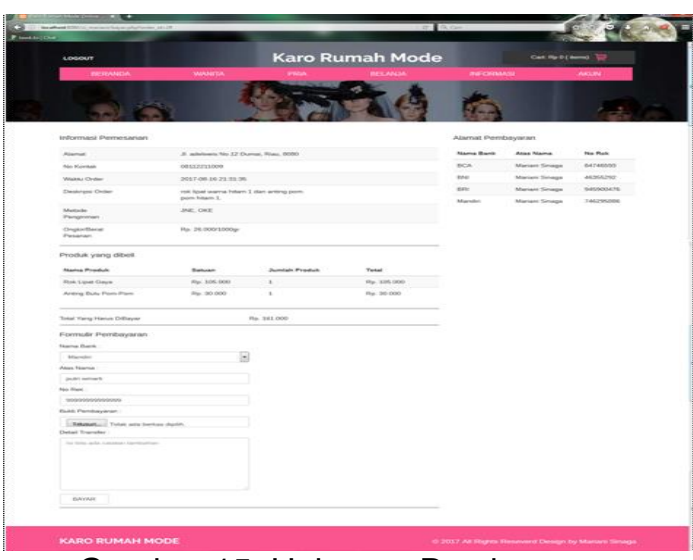

Gambar 15. Halaman Pembayaran

Adapun laporan yang dihasilkan dari system informasi penjualan ini meliputi laporan penjualan online per-periode seperti yang ditunjukkan pada Gambar 16, laporan penjualan langsung per-periode dapat dilihat pada Gambar 17.

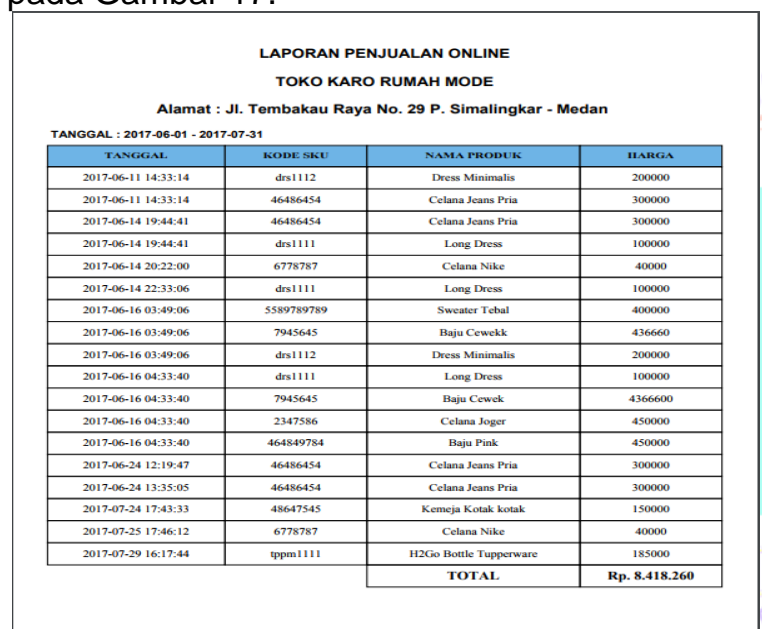

Gambar 16. Laporan Penjualan Online

\begin{tabular}{|c|c|c|c|}
\hline \multicolumn{4}{|c|}{$\begin{array}{l}\text { LAPORAN PENJUALAN LANGSUNG } \\
\text { TOKO KARO RUMAH MODE } \\
\text { Alamat : Jl. Tembakau Raya No. } 29 \text { P. Simalingkar - Medan }\end{array}$} \\
\hline TANGGAL & KODE SKU & NAMA PRODUK & HARGA \\
\hline $2017-07-26$ 19:55:25 & kbyy111 & Brokat Bangkok & 550000 \\
\hline $\begin{array}{l}2017-07-31 \text { 00:01:53 } \\
\end{array}$ & $\operatorname{atg} 1113$ & Anting Wanita & 26500 \\
\hline 2017-07-31 00:01:53 & btkw11111 & Batik Wanita Modem & 270000 \\
\hline $2017-08-08$ 13:52:31 & kmip11111 & Kemcja Casual Pria & 67000 \\
\hline $2017-08-08$ 13:52:31 & glgw1111 & $\begin{array}{l}\text { Gelang Wanita } \\
\end{array}$ & 45000 \\
\hline 2017-08-08 13:52:51 & clap1111 & Celana Kargo & 230000 \\
\hline $2017-08-08$ 13:54:57 & blkcl1112 & Batik Sarimbit Couple & 300000 \\
\hline $2017-08-08$ 13:54:57 & kbyl1113 & Kcbaya Brukat & 130000 \\
\hline 2017-08-10 12:38:50 & clmp1112 & $\begin{array}{l}\text { Celana Pendek } \\
\end{array}$ & 100000 \\
\hline $2017-08-11$ 12:06:16 & clapl111 & Celana Kargo & 230000 \\
\hline 2017-08-14 10:30:06 & kmpl1112 & Kemcja Formal Pria & 99900 \\
\hline 2017-08-14 10:30:06 & bjidt11112 & Sectlan Baju Tidur & 155000 \\
\hline 2017-08-25 05:51:46 & jkw1111 & Jaket Wanita Modem & 235000 \\
\hline 2017-08-25 06:21:26 & drs 11112 & Dress Minimalis & 200000 \\
\hline 2017-08-25 11:-31:50 & jkpl1111 & Jaket Kulit & 340000 \\
\hline 2017-08-25 11:31:50 & 6778787 & Celana Nike & 40000 \\
\hline & & TOTAL & Rp. 3.018.400 \\
\hline
\end{tabular}

Gambar 17. Laporan Penjualan Langsung
Laporan penjualan detail kasir berisi informasi produk yang terjual pada penjualan langsung di toko oleh masing-masing kasir dapat dilihat pada Gambar 18, laporan produk kembali dapat dilihat pada Gambar 19.

\begin{tabular}{|c|c|c|c|}
\hline \multicolumn{4}{|c|}{$\begin{array}{l}\text { LAPORAN PENJUALAN PER KASIR } \\
\text { TOKO KARO RUMAH MODE }\end{array}$} \\
\hline \multirow{2}{*}{ ID Kasir : 6} & \multirow[b]{2}{*}{ NAMA PRODUK } & \multicolumn{2}{|c|}{ TANGGAL : 2017-07-01 - 2017-07-31 } \\
\hline & & \begin{tabular}{|l|} 
JIMLAH PENJUALAN \\
\end{tabular} & JUMLAH PENDAPATAN \\
\hline atg1113 & Anting Wanita & 1 & Rp. 26.500 \\
\hline bthw1111 & Batik Wanita Modem & 1 & Rp. 270.000 \\
\hline kby111 & Brokat Bangkok & 1 & Rp. 550.000 \\
\hline & & TOTAL & Rp. 846.500 \\
\hline
\end{tabular}

Gambar 18. Laporan Penjualan Detail Kasir

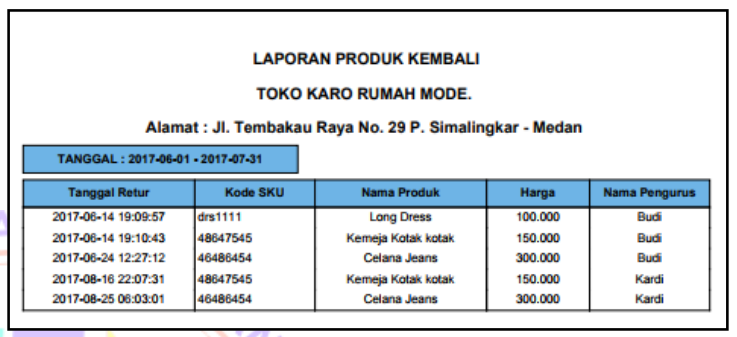

Gambar 19. Laporan Produk Kembali

Laporan stok produk berisi informasi daftar stok produk yang ada di database website sistem informasi penjualan pada toko karo rumah modedapat dilihat pada Gambar 20.

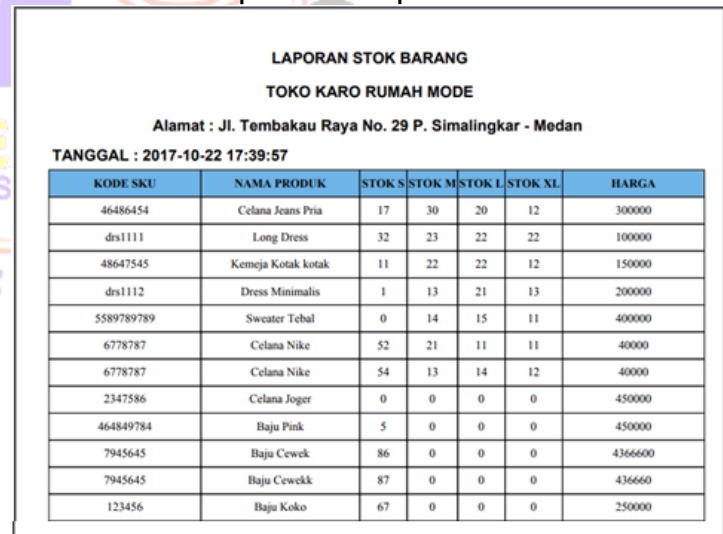

Gambar 20. Laporan Stok Produk

\section{KESIMPULAN}

Beberapa kesimpulan yang dapat diambil dari penerapan sistem terhadap permasalahan yang ada dalam perancangan Sistem Informasi penjualan pada Karo Rumah Mode Medan adalah sebagai berikut:

1. Dengan adanya perancangan sistem informasi e-commerce pada Karo Rumah Mode dapat memberikan solusi terhadap permasalahan yang dihadapi oleh Karo Rumah Mode dalam proses penjualan 
produk, dokumentasi laporan penjualan dan stok barang, serta sebagai solusi pemasaran produk bagi toko.

2. Konsumen dapat memesan produk pada Karo Rumah Mode ini dimana saja yang terhubung dengan jaringan internet, konsumen hanya perlu memilih produk dan melakukan pemesanan.

\section{DAFTAR PUSTAKA}

[1]. Adiprayitno, R. Ananda Irhasr Maha dan Edwar, Muhammad. "Pengaruh Kualitas Layanan Dan Harga Terhadap Keputusan Penggunaan Jasa Pengiriman Barang JNE (Jalur Nugraha Ekakurir) Di Agen Putro AgungWetan Surabaya". Jurnal Pendidikan Tata Niaga (JPTN), ISSN: 2337-6708 Volume 01 Nomor 01 Tahun 2017 (Surabaya, 2017).

[2]. Belalawe, Mateus Mas. "Tinjauan keamanan sistem transaksi dan pembayaran Pada e-commerce (Studi Kasus: Toko Online www.buahonline.com)". Jurnal Seminar Nasional Yogyakarta ISSN: 2089-9815 (Yogyakarta,Maret 2013).

[3]. Christopel, S. M. A, dkk. "Rancang Bangun Sistem Informasi Penjualan Berbasis Cloud Bagi Usaha Kecil Dan Menengah Di Indonesia (Studi Kasus: Toko "Toko Besar")". Jurnal Sistem Informasi JSIKA 2, 52-59 (Surabaya, 2013).

[4]. Fatansyah. 2012. Basis Data Edisi Revisi. Bandung: Informatika.

[5]. Kadir, Abdul. 2014. Pengenalan Sistem Informasi. Yogyakarta: Andi, Edisi Revisi.

[6]. Nore, Victor Nicolas. "Perancangan Sistem Informasi Penjualan dan Pemesanan Produk Berbasis Web". Jurnal International Association Of Universities, 1:1, 27 - 29 (Bandung, Januari 2013).

[7]. Sibero, Alexander F.K. 2013. Web Programming Power Pack. Jakarta:MediaKom.

[8]. S, Rosa.A dan Shalahuddin, M. 2016. Rekayasa Perangkat Lunak. Bandung: Informatika.

[9]. Widodo, Prabowo Pudjo. 2011. Menggunakan UML, Unified Modeling Language. Bandung: Informatika

[10]. Tonni Limbong, 2014, Sistem Informasi Kehadiran Dosen Dan Jadwal Pengganti Perkuliahan Berbasis Short Message Service (SMS), Informasi Dan Teknologi
IImiah (INTI) Budi Darma,LPPM STMIK Budi Darma.

[11]. Lamhot Sitorus, 2015. Algoritma Dan Pemrograman, Andi Offset, Yogyakarta. 